\title{
DEVELOPING A COMMON LAW OF HYDRAULIC FRACTURING
}

\author{
David E. Pierce*
}

\section{INTRODUCTION}

Hydraulic fracturing is the process of creating fissures in a subsurface rock structure by pumping pressurized material down a well drilled into the rock structure. ${ }^{1}$ The process is undertaken to increase the drainage area within the rock structure that is connected to the well. ${ }^{2}$ In addition to improving the productive capacity of oil and gas wells, hydraulic fracturing is absolutely necessary to profitably develop oil and gas from shale rock formations and other "tight" formations. ${ }^{3}$

Hydraulic fracturing has been employed in Pennsylvania for over 50 years ${ }^{4}$ and in other oil and gas producing states for over 60 years. ${ }^{5}$ Historian Craig Miner offers the following 1953 hydraulic fracturing testimonial by oilman Ben Gralapp of Winfield, Kansas:

\footnotetext{
It's the most astounding thing I ever heard of. It's responsible for 500 or 600 wells being drilled in this territory that otherwise would not have been drilled. Wells that didn't show a teaspoon when they came in are making forty-five barrels a day. ${ }^{6}$
}

Geologist William S. Lytle, in writing about hydraulic fracturing activities in Pennsylvania, noted that a sharp increase in fracturing deep productive gas zones occurred in $1954 .^{7}$ Commenting on the state of the practice in 1965 , Mr. Lytle reported that "most of the deep gas wells drilled since 1957 have

\footnotetext{
2. Martin S. Raymond \& William L. Leffler, Oil and Gas Production in Nontechnical LANGUAGE 218 (2006)

3. Id. at $217-18$

4. William S. Lytle, Results of Stimulating the Oil and Gas Sands by Hydraulic Fracturing in Pennsylvania, 7 Interstate Oil Compact Commission Committee Bull. 17 (June 1965).

5. Hydraulic fracturing techniques were being employed in Kansas oil fields as early as 1948 . Craig Miner, Discovery! Cycles of Change in the Kansas Oil \& Gas Industry 1860-1987, 218 (1987).

6. $\quad I d$.

7. Lytle, supra note 4, at 17.
} (1991)

* Professor, Washburn University School of Law Topeka, Kansas

1. Norman J. Hyne, Dictionary of Petroleum Exploration, Drilling \& Production 249 
been fractured." ${ }^{8} \mathrm{He}$ also added that most of the shallow gas wells were being fractured. ${ }^{9}$ By 1961, the benefits of fracturing oil wells had also been proven. ${ }^{10}$ Mr. Lytle summed up the Pennsylvania situation as it existed in 1965 stating: "The hydraulic fracturing boom is off to a good start." 11

Although the "hydraulic fracturing boom" in 1965 may have been an event of interest only to geologists and oil companies, today's fracturing boom in the Marcellus Shale, and other shale formations, has sparked the interest of landowners, environmental groups, and government officials, among others. Because shale formations cannot be developed without using hydraulic fracturing, blocking hydraulic fracturing becomes a way of blocking the intensive land use associated with large scale shale development. The land use battle will take place primarily on the environmental front, which other symposium participants will address. To a more limited extent, the battle will also be waged on the common law front as landowners seek to block or discourage hydraulic fracturing employing trespass and related claims.

Regarding existing shale development, trespass claims can have a direct effect on the use of hydraulic fracturing. Because it is not possible to control the precise location of fissures created by the fracturing process, imposing liability for fissures that cross property boundaries would cause operators to limit their use of hydraulic fracturing and may, ultimately, cause them to abandon the process altogether-which would mean abandoning development of most shale formations.

This article explores the three common law dimensions of hydraulic fracturing: property, tort, and contract. Although there is a limited amount of "law" on hydraulic fracturing, sufficient case law and commentary exist to frame and evaluate the analysis likely to guide development of a common law of hydraulic fracturing.

\section{THE PROPERTY DIMENSION OF HYDRAULIC FRACTURING}

The most difficult hydraulic fracturing issues concern subsurface property rights. The surface of the land, however, will also be impacted. Because

8. Id. at 20. He reported that following fracture treatment the wells increased production by $500 \%$.

9. Id. ("In 1963, there were 144 gas wells drilled and 122 of them were fractured."). Production following fracturing of these wells increased "from four to 27 times." Id.

10. Id. at 20-21 (quoting a U.S. Bureau of Mines study of oil well fracturing in the Warren County, Pennsylvania area: “'Available production data from single-stage-fractured new wells indicate that average cumulative oil production during the first 100 days will be 8.5 times greater than the production ordinarily obtained from a well shot with liquid nitroglycerine."').

11. Id. at 21 . 
surface issues involve a more traditional application of easement law, they will be addressed first, followed by subsurface issues which require a more complex, and less traditional, analysis.

\section{A. Surface Issues}

The hydraulic fracturing process involves the temporary use of surface locations for the necessary vehicles, equipment, and associated facilities. ${ }^{12}$ If the oil and gas mineral estate has been previously severed from the "surface" estate, the right to use the surface of the land will be governed by the terms of the conveyance document creating the separate estates. If, as is often the case, the document creating the severance is silent regarding the mineral owner's use of the surface, the mineral owner will be deemed to have a sort of easement by necessity. ${ }^{13}$ This implied easement by necessity gives the mineral owner the right to make "reasonable use" of the surface to explore for, develop, and produce oil and gas from the mineral estate. ${ }^{14}$

If the minerals have not been severed, and the owner of the land enters into an oil and gas lease with a developer, the express easements contained in the oil and gas lease will define the parties' rights. In most leases, however, there typically will not be an express reference to "hydraulic fracturing" or

12. Norman J. Hyne, Nontechnical Guide to Petroleum Geology, Exploration, Drilling, AND Production 425 ( $2 \mathrm{~d}$ ed. 2001) (discussing the equipment used to conduct hydraulic fracturing operations)

13. The facts are similar to the conveyance of a land-locked tract of land within a larger tract. In the mineral situation the mineral estate is severed but access to the severed estate requires access from the surface, which is owned by the other party to the conveyance. In those situations access will be provided to the land-locked interest because, absent language in the deed providing otherwise, it is presumed the parties intended the land-locked interest to have access. Restatement (Third) of Prop: Servitudes $\S 2.15$ (2000) ("Servitudes Created By Necessity"). Although the Restatement (Third) of Property applies the same easement by necessity analysis to a severed mineral interest that is applied to a land-locked surface tract, the Pennsylvania Supreme Court, in Chartiers Block Coal Co. v. Mellon, 25 A. 597 (Pa. 1893), observed:

While there is some analogy between such right and the common-law right of way of necessity over the surface, we quite agree with the learned judge below that it would require a large modification of the common-law rule. We do not see our way clear to apply the doctrine of a surface right of way of necessity to the facts of this case.

25 A. at 599 . The court recognized that an easement by necessity existed, but found that the issues concerning competing rights in separately owned minerals at differing depths created complexities that the law governing the land-locked surface model could not resolve.

14. Belden \& Blake Corp. v. Dep't of Conservation and Natural Res., 969 A.2d 528 (Pa. 2009) (citing Chartiers, 25 A. 597 as the "seminal case setting forth a subsurface owner's rights with respect to the surface owner's rights"). Belden reaffirmed that the implied easement will be defined by what is "reasonable." 969 A.2d at 532 n.6. 
other form of "fracturing." 15 Nevertheless, the right to conduct hydraulic fracturing will, in most cases, be found to be encompassed by the broader easement grants for "the purpose of exploring, prospecting, drilling and mining for and producing oil and gas. . .."16 Any doubts will likely be resolved by applying an analysis similar to that used in the Restatement (Third) of Property where it provides:

Except as limited by the terms of the servitude ... the holder of an easement or profit $\ldots$ is entitled to use the servient estate in a manner that is reasonably necessary for the convenient enjoyment of the servitude. The manner, frequency, and intensity of the use may change over time to take advantage of developments in technology and to accommodate normal development of the dominant estate or enterprise benefited by the servitude. Unless authorized by the terms of the servitude, the holder is not entitled to cause unreasonable damage to the servient estate or interfere unreasonably with its enjoyment. ${ }^{17}$

Hydraulic fracturing would seem to easily fit within either the "reasonably necessary for the convenient enjoyment" category or the "developments in technology" category.

In a 1965 case, the Oklahoma Supreme Court recognized hydraulic fracturing as an accepted development technology, noting:

The testimony showed that sandfracing was first discovered in 1948 and was first used commercially in 1949. It was used at certain places in Southern Oklahoma in 1950 and 1951. Sandfracing was first used in the Hewitt Pool in 1956. The first time the defendant used the fracing process in the Hewitt Pool was in January, 1957. ${ }^{18}$

15. This will depend largely on the vintage of the lease and the contemplated operations under the lease. For example, if the parties are entering into a lease today when a specific type of development is contemplated, the parties are likely to expressly reference fracturing. Consider the following granting language in a lease created for use in Kentucky where coalbed methane operations were contemplated: "together with such exclusive rights as may be necessary or convenient for Lessee . . . to explore for, develop, produce, measure, and market production from the Leasehold . . . using methods and techniques which are not restricted to current technology, including the right to ... drill (either vertically, horizontally or directionally), . . to stimulate or fracture all coal formations, seams or other strata or formations. ..." John S. Lowe et al., Forms Manual to Accompany Cases and Materials on Oil and Gas Law 168, lines $16-23$ (5th ed. 2008).

16. Id. at 146, lines 10-11 (A.A.P.L. Form 675 Oil and Gas Lease).

17. Restatement (Third) of Prop: Servitudes $§ 4.10$ (2000) (“Use Rights Conferred By A Servitude").

18. Crocker v. Humble Oil \& Refining Co., 419 P.2d 265, 271 (Okla. 1965). The issue in this case was whether the lessee breached an implied covenant to further develop leased lands. As discussed in section IV. of this article, recognition of hydraulic fracturing as a production technique played the central roll in resolving the implied covenant issues. See infra notes 61-64 and accompanying text. 
The term "sandfracing" was used by the court in Crocker to describe the same activity as encompassed by the term "hydraulic fracturing.","

Hydraulic fracturing appears to be clearly within the scope of the implied right to make "reasonable use" of the surface. It also appears to fall well within the scope of express easement rights to "explore" and "develop" found in most oil and gas leases. The likely disputes will focus not on whether hydraulic fracturing can be pursued, but rather on "how" it is pursued. This will be determined by defining, on a site specific basis, what is "reasonably necessary for the convenient enjoyment of the servitude." ${ }^{20}$

\section{B. Subsurface Issues}

The subsurface property issues associated with hydraulic fracturing concern the movement of fissures, frac fluids, and proppants across boundary lines. ${ }^{21}$ If the area invaded by fissures, frac fluids, and proppants is "owned" by someone who has not consented to the hydraulic fracturing, they will assert that the unauthorized entry is a trespass. ${ }^{22}$ The trespass issue in this situation is actually a "property" issue as opposed to a "tort" issue. The proper, or even the improper, analysis of the property issue should, in most cases, resolve the tort issue. ${ }^{23}$ As with most property issues, the task is defining the rights of the parties as they relate to the precise question before the court. ${ }^{24}$

19. The trial court used the term "hydraulic-fracturing" interchangeably with the term "sandfracing." Crocker, 419 P.2d at 271. "Sandfracing" has been defined as: "An operation designed to loosen or break up tight formations which contain oil or gas, thus causing such formations to have more permeability and greater production.” Patrick H. Martin \& Bruce M. Kramer, Williams \& Meyers Manual of Oil AND GAS TERMS 971 (10th ed. 1997).

20. Restatement (Third) OF Prop: Servitudes $\S 4.10$ (2000). The Restatement also attempts to define limits on the easement holder's rights noting: "the servitude owner is not entitled to cause any greater damage than that contemplated by the parties, or reasonably necessary to accomplish the purposes of the servitude." Id. at cmt. g.

21. "Frac fluids" refer to the water, sand, and chemical mixture that is injected into the rock structure as a liquid. Guide to Petroleum, supra note 12, at 423. "Proppants" or "propping agents" can consist of quartz sand grains or any material capable of being injected as a frac fluid slurry into the fractured areas and strong enough to "prop" or hold open the rock structure once the frac fluid is removed. Id. at 424 .

22. This issue was addressed by the Texas Supreme Court in Coastal Oil \& Gas Corp. v. Garza Energy Trust, 268 S.W.3d 1, 4 (Tex. 2008), where the court stated the issue as: "whether subsurface hydraulic fracturing of a natural gas well that extends into another's property is a trespass ...."

23. Either it will, or it will not, be a trespass.

24. As noted by Carol Rose, a renowned modern property law theorist, the definition of property is an evolving process because it is not efficient to address all the contours of ownership in the abstract. Instead, the scope of property ownership is more fully defined as issues arise at a time when it is necessary, and therefore efficient, to address them. Carol M. Rose, A Dozen Propositions on Private Property, Public 
The question is whether an owner of property in an oil and gas reservoir has the right to conduct hydraulic fracturing operations on its well when the process is intentionally undertaken to: (1) create fissures that extend into neighboring parts of the reservoir owned by others; (2) send frac fluids and proppants into neighboring parts of the reservoir; and (3) increase the productivity of its well by draining more oil and gas from the reservoir, including parts of the reservoir owned by others. To analyze the trespass issue, the question assumes a "worst case" scenario for the party engaging in hydraulic fracturing; they intend the process to physically extend into, and drain, surrounding reservoir properties.

\section{The Ad coelum, Trespass, and Rule of Capture Analyses}

Courts $^{25}$ and commentators ${ }^{26}$ have addressed this issue by first applying the ad coelum doctrine. ${ }^{27}$ Although the doctrine may not be expressly referenced, its efficacy is acknowledged by giving primary importance to the orientation of fissures, frac fluids, and proppants to property boundary lines. Applying a surface boundary analysis, a physical intrusion of neighboring lands is a trespass. ${ }^{28}$ Some courts, however, have been willing to excuse the

Rights, and the New Takings Legislation, 53 WASH. \& LeE L. ReV. 265, 269 (1996).

25. Mission Res., Inc. v. Garza Energy Trust, 166 S.W.3d 301 (Tex. App. 2005), rev'd, Coastal Oil \& Gas Corp. v. Garza Energy Trust, 268 S.W.3d 1 (Tex. 2008) (the court of appeals held that an actionable trespass occurred and upheld the trial court's award of $\$ 543,776$ in drainage damages and $\$ 10$ million in punitive damages; the supreme court reversed holding that the rule of capture negated the drainage damages and the attendant punitive damages).

26. Terry D. Ragsdale, Hydraulic Fracturing: The Stealthy Subsurface Trespass, 28 Tulsa L. J. 311,339 (1993) ("From both a functional and physical perspective, a hydraulic fracture is largely analogous to a directionally drilled well."). Professor Anderson also analyzes the intrusion of a fracture fissure into adjacent lands as a trespass but would not make it an actionable trespass unless the adjacent subsurface owner suffers substantial damages. Owen L. Anderson, Subsurface "Trespass": A Man's Subsurface Is Not His Castle, 49 Washburn L. J. 247, 258-59 (2010) [hereinafter Anderson, Subsurface "Trespass"]. Professors Anderson and Kramer would also employ the rule of capture in various ways to avoid an actionable subsurface trespass associated with hydraulic fracturing. Bruce M. Kramer \& Owen L. Anderson, The Rule of Capture-An Oil and Gas Perspective, 35 EnvtL. L. 899, 935-36 (2005). Laura H. Burney \& Norman J. Hyne, Hydraulic Fracturing: Stimulating Your Well or Trespassing?, 44 Rocky MTN. Min. L. INST. 19-1, 19-17 (1998) ("the question is whether fracing constitutes a permissible process under the rule of capture or an impermissible trespass").

27. As used in this article, "ad coleum doctrine" is an abbreviated term for the legal maxim cujus est solum ejus est usque ad coelum et ad inferos, which is translated to mean: "To whomsoever the soil belongs, he owns also to the sky and to the depths." BLACK's LAw Dictionary 341 (5th ed. 1979).

28. Restatement (Second) OF Torts § 159 (1965) (“Except as stated in Subsection (2) [regarding flight by aircraft in the air above land], a trespass may be committed on, beneath, or above the surface of the earth."). 
trespass when the conduct is viewed as socially desirable. For example, in Railroad Commission v. Manziel, ${ }^{29}$ the oil and gas regulatory commission authorized a secondary recovery project and approved the drilling of an injection well near Manziel's lease boundary. Despite Manziel's objections, the commission's order was upheld noting the importance of promoting secondary recovery operations. ${ }^{30}$ The issue was subsequently addressed in a private context in Baumgartner v. Gulf Oil Corp.,${ }^{31}$ where the adjacent lessee affected by the secondary recovery operation sued the operator for trespass. The court held the facts would not support a willful trespass claim. ${ }^{32}$ Presumably, the adjacent landowner would be limited to seeking damages for their actual lost profits, if any. This is somewhat similar to the hydraulic fracturing solution offered by Professor Anderson, who would exempt the invasion by fissures, frac fluids, and proppants unless they result in substantial damage to the adjacent landowner. ${ }^{33}$

The most recent judicial analysis of the issue comes from the Texas Supreme Court where it suggests the subsurface dimension of the ad coelum doctrine might need to be limited to accommodate hydraulic fracturing. ${ }^{34}$ In Coastal Oil \& Gas Corp. v. Garza Energy Trust, ${ }^{35}$ Coastal conducted hydraulic fracturing operations on its tract A, which the court assumed for its analysis resulted in a physical invasion of Garza's tract $B$, and drainage of hydrocarbons from tract $\mathrm{B}$ to the well on tract $\mathrm{A} \cdot{ }^{36}$ Although not necessary for a resolution of the issues in the case, Justice Hecht, writing for the majority, felt compelled to state:

Had Coastal caused something like proppants to be deposited on the surface of Share 13 [tract B], it would be liable for trespass, and from the ancient common law maxim that land ownership extends to the sky above and the earth's center below, one might

29. 361 S.W.2d 560 (Tex. 1962).

30. Id. at 568. See John W. Broomes, Wrestling with a Downhole Dilemma: Subsurface Trespass, Correlative Rights, and the Need for Hydraulic Fracturing in Tight Formations, 53 Rock Y MTn. Min. L. INST. $20-1,20-8$ to $20-10$ (2007).

31. 168 N.W.2d 510 (Neb. 1969).

32. Id. at 516 .

33. Anderson, Subsurface "Trespass," supra note 26, at 258-59.

34. Coastal Oil \& Gas Corp. v. Garza Energy Trust, 268 S.W.3d 1 (Tex. 2008).

35. Id.

36. This operative scenario is acknowledged by the court by opening its opinion with the following statement: "The primary issue in this appeal is whether subsurface hydraulic fracturing of a natural gas well that extends into another's property is a trespass for which the value of gas drained as a result may be recovered as damages." Coastal, 268 S.W.3d at 4 . As will be discussed, the court answers only the damages portion of the issue: "We hold that the rule of capture bars recovery of such damages." Id. As to the trespass part of the "primary issue" the court responded: "We need not decide the broader issue here." Id. at 12. 
extrapolate that the same rule should apply two miles below the surface. But that maxim-cujus est solum ejus est usque ad coelum et ad inferos- "has no place in the modern world." Wheeling an airplane across the surface of one's property without permission is a trespass; flying the plane through the airspace two miles above the property is not. Lord Coke, who pronounced the maxim, did not consider the possibility of airplanes. But neither did he imagine oil wells. The law of trespass need no more be the same two miles below the surface than two miles above. ${ }^{37}$

The court seems to be setting the stage for the next hydraulic fracturing trespass case.

The court dodges the underlying trespass issue in Coastal by noting the complaining royalty owners have only a possibility of reverter in the oil and gas beneath their land; a nonpossessory interest in the minerals. ${ }^{38}$ As such, the royalty owners cannot sue for trespass to the realty because that is an injury to the right of possession. ${ }^{39}$ One might ask why doesn't the tract B lessee sue to protect their right of possession? In this case, Coastal was the owner of tract $\mathrm{A}$ and the lessee of tract $B .^{40}$ Coastal held the right of possession in tract $\mathrm{B}$ and therefore any claim for trespass to the realty would have to be brought by Coastal. Obviously, Coastal chose not to sue itself. In any event, Coastal at no time believed its royalty owners had been wronged. ${ }^{41}$

Although the tract $\mathrm{B}$ royalty owners cannot bring a trespass quare clausum fregit action, which requires a possessory interest, they could bring a trespass on the case action to recover for injury to their possibility of reverter. ${ }^{42}$ The major difference is they must prove actual permanent harm to the property. ${ }^{43}$ The only harm alleged by the royalty owners in Coastal, was drainage from tract $\mathrm{B}$ to a well on tract $\mathrm{A} .{ }^{44}$ This is the point in the opinion where the court characterized Garza's damages as being negated by the rule of capture because the production at issue was "produced from a lawful well bottomed on the property [tract A] . .."45 The court focused on the tract A well bore, noting it does not violate any statute or regulation, and concluded: "Thus, the gas he claims to have lost simply does not belong to him."46

37. Id. at 11 (citations omitted).

38. Id. at 9 .

39. Id.

40. Id. at 5 .

41. Throughout the litigation Coastal contended no effective fissures were created in tract B that would have caused drainage to occur. $I d$. at 8 .

42. Id. at $9-10$.

43. Id. at 10 .

44. Id. at $12-13$

45. Id. at 13 .

46. $I d$. 
Because the drained gas was produced through the tract A well bore, the gas belongs to A [Coastal] under the rule of capture.

But note, the critical issue is not whether the draining well on tract A complied with statutes and regulations, the issue is the legitimacy of the hydraulic fracturing which the court assumes made the connection between the tract $\mathrm{A}$ well bore and the tract $\mathrm{B}$ oil and gas. Without evaluating the legitimacy of the hydraulic fracturing connection, it is not possible to assess whether the rule of capture can be properly applied to the resulting drainage. Analytically, it seems impossible to apply the rule of capture, for any purpose, without first addressing the legitimacy of the act resulting in production of the oil and gas at issue. The legitimacy of the physical invasion of the plaintiff's property should determine whether the defendant can rely upon the rule of capture as a defense.

\section{The Path Not Taken, or Even Acknowledged: The Reservoir Community} Analysis

Although the Coastal case has been touted as an important case on the subject that is likely to lead the way for other courts, its main virtue is in defining the path courts should avoid. The basic error in the Coastal court's property analysis is that it treats Coastal's rights in the oil and gas reservoir as though it were a compartmentalized tract of surface land. In reality it is an inter-connected common reservoir where no owner is able to fence-off his or her tract from the other reservoir owners. Coastal, the tract B plaintiffs, and the other owners of property in the Vicksburg T tight sandstone formation, ${ }^{47}$ are all members of the "Vicksburg T reservoir community." 48

To illustrate the reservoir community analysis, assume a Pennsylvania court is called upon to evaluate hydraulic fracturing within the Vicksburg $\mathrm{T}$ reservoir community. Although surface boundaries will be important in defining membership, and the areal extent of membership, in the Vicksburg $\mathrm{T}$ reservoir community, surface boundaries do not define what can, and cannot, be done within the community. For example, if hydraulic fracturing

47. The hydraulic fracturing that was the focus of the Coastal case took place in what the court describes as the "Vicksburg T . . a 'tight' sandstone formation, relatively imporous and impermeable, from which natural gas cannot be commercially produced without hydraulic fracturing stimulation ...." $I d$. at 6.

48. Professor Kuntz appears to have been the first scholar to use the term "special community" in describing the relationships of owners in an oil and gas reservoir. 1 EugEne Kuntz, A Treatise On the LAW OF OIL AND Gas 120 (1987). 
is necessary for community members to enjoy the mineral wealth associated with the community, ${ }^{49}$ then hydraulic fracturing should be a permissible, and indeed promoted, activity. Because the community is "connected" throughout, it would be unreasonable to expect that fissures, frac fluids, and proppants will not cross surface boundaries, or that there will not be cross-boundary drainage. The traditional "right to exclude" associated with surface boundaries, simply does not exist in the normal hydraulic fracturing scenario. All community members should have the concurrent right to make use of lands that lie beyond surface boundaries when pursuing legitimate hydraulic fracturing activities.

Every community member's rights in the reservoir are relative to those of the other members. We could even call them "correlative" rights,${ }^{50}$ but it is not necessary to label them. Using the term correlative rights risks channeling the analysis of the property right instead of merely acknowledging the physical facts that comprise and define the property interest. It is enough to say that each community member possesses certain individual rights that are defined by surface boundaries, ${ }^{51}$ as well as certain collective rights in the reservoir that extend beyond surface boundaries. The collective rights are shared with the other reservoir members who have a sort of non-exclusive right to "use" the reservoir to conduct legitimate development operations that comport with community standards.$^{52}$ In the context of hydraulic fracturing, the right to use

49. This fact was firmly established in the Coastal case where the court observed:

The experts in this case agree on two important things. One is that hydraulic fracturing is not optional; it is essential to the recovery of oil and gas in many areas, including the Vicksburg

$\mathrm{T}$ formation in this case... The other is that hydraulic fracturing cannot be performed both

to maximize reasonable commercial effectiveness and to avoid all drainage. Some drainage is virtually unavoidable.

268 S.W.3d at 16.

50. The term "correlative rights," when applied to oil and gas, can be used in two differing contexts. The first context is state regulation to prevent waste by constraining in some way the rule of capture. If a person's capture rights are restricted, the state must ensure other owners in the reservoir are similarly restricted to protect each owner's correlative rights. See generally Zinke \& Trumbo, Ltd. v. State Corp. Comm'n, 749 P.2d 21, 28 (Kan. 1988) (commission obligated by statute to consider impact of hydraulic fracturing when adopting a well allowable formula). The second context is recognition that any owner operating in a reservoir has the ability to impact other reservoir owners. The Texas Supreme Court focused on this common law correlative rights concept in Elliff v. Texon Drilling Co., 210 S.W.2d 558, 563 (Tex. 1948) (owners in reservoir must "use due care to avoid the negligent waste or destruction" of oil and gas in the reservoir).

51. Which will be used to determine eligibility to be a member in the reservoir community and for such purposes as determining their right to drill a well or to participate in production from a pooled spacing unit.

52. Professor Kuntz would characterize this as defining the "social acceptability of conduct within such community ...." KunTZ, supra note 48. 
the reservoir would include occupying with fissure, fluid, and proppant, portions of the reservoir that lie beyond a member's surface boundaries. This physical intrusion across another member's boundaries would be permissible to the extent necessary, or convenient, to prudently maximize recovery of the oil and gas through a well on the member's land or pooled spacing unit.

Reservoir community standards will determine whether an activity is permissible. Community standards will be reservoir specific and based upon accepted usages, best practices, and proven techniques. The degree to which a technique must be accepted or proven will vary depending upon its potential impact on the reservoir that extends beyond a member's tract.

When evaluating conduct within a specific reservoir, such as the Vicksburg T, the focus should be solely on what is appropriate for maximizing wealth from within the Vicksburg T reservoir community. The community members may, or may not, have an interest in the surface, the coal, or other mineral formations above or below the Vicksburg T. Therefore, it would seem inappropriate to temper reservoir community standards by considering impacts on other estates, such as the surface, coal, or other oil and gas formations. Such issues will be considered in other contexts and should not impact the more limited and focused issue of what is acceptable conduct within, for example, the Vicksburg T reservoir community.

Once the connected nature of the reservoir is recognized, reservoir activities that cross a surface boundary line extended downward will not necessarily be a trespass. Accurate definition of the property interests can avoid turning a legitimate use of common property into a tort against individual property.

\section{THE TORT DIMENSION OF HYDRAULIC FRACTURING}

\section{A. Trespass}

The tort dimension of hydraulic fracturing, at least as it relates to the tort of trespass, is inexorably tied to the property dimension. As noted above, it is most likely that courts will manipulate the property dimension to achieve the desired outcome in the tort dimension. Another way to address the issue is the "tort" or "no tort" approach. Justice Willett, in his concurring opinion in the Coastal case, frankly describes this approach, stating that:

To many people, a subsurface intrusion of fissures, fluid, and proppant invites a simple application of rudimentary trespass principles. Why not call a tort a tort?

Well, we affix that common-law label, and not every technical intrusion, no matter 
how small, warrants damages, no matter how large. Trespass is a court-defined doctrine, and it falls squarely on this Court's shoulders to decide what is actionable. In doing so, we made clear in Manziel the common law must permit common-sense accommodations for technological breakthroughs that benefit society. ${ }^{53}$

As noted in the previous section of this article, by properly and accurately defining the true nature of "property" in the reservoir at issue, the trespass issue is avoided altogether. The entry of fissures, frac fluids, and proppants into adjacent portions of the reservoir become privileged uses as opposed to tortious intrusions.

\section{B. Torts Associated with the Development Process}

As with any industrial activity, hydraulic fracturing will be the object of suits seeking to recover for personal injury and property damage. Consider the allegations in Florentino v. Cabot Oil \& Gas Corporation, ${ }^{54}$ where sixty-three individuals residing near Cabot's operations asserted they were injured by Cabot's "improperly conducted hydrofracturing" and "other natural gas production activities...." The court denied Cabot's motion to dismiss the plaintiffs' claims asserting strict liability, negligence per se, medical monitoring benefits, and response costs under Pennsylvania's Hazardous Sites Cleanup Act. ${ }^{56}$ The court described the underlying basis for the plaintiffs' lawsuit as follows:

Plaintiffs maintain that they have experienced property damage and physical illness, that they live in constant fear of future illness, and that they suffer severe emotional distress. Thus, Plaintiffs request an injunction prohibiting future natural gas operations, and seek compensatory and punitive damages, the cost of future health monitoring, attorneys' fees and costs, and any other appropriate relief. ${ }^{57}$

53. Coastal, 268 S.W.3d at 36 (Willett, J., concurring).

54. No. 09-cv-2284, 2010 WL 4595524 (M.D. Pa. Nov. 15, 2010).

55. Id. at *2. Similar claims are being made by the plaintiffs in Berish v. Southwestern Energy Prod. Co., No. 3:10-cv-1981, 2011 WL 382420 (M.D. Pa. Feb. 3, 2011) (refusing to dismiss, at the pre-discovery stage of the litigation, claim asserting that hydraulic fracturing is an abnormally dangerous activity so that strict liability will be imposed).

56. Fiorentino, $2010 \mathrm{WL} 4595524$, at $* 4$ (response costs), *5 (strict liability), *6 (medical monitoring trust fund), $* 9$ (negligence per se). Claims made that were not challenged in Cabot's motion to dismiss included: negligence, private nuisance, breach of contract, and fraudulent misrepresentation. Id. at *1. The plaintiffs' "gross negligence" claim was dismissed with the court holding a claim for "gross" negligence is not recognized under Pennsylvania law. Id. at *7. The court, however, allowed the gross negligence allegation to remain, not as a cause of action, but as support for plaintiffs' request for punitive damages. $I d$. at $* 8$.

57. Id. at $* 2$. 
As the law develops in this area, legislative action can be expected to add to the mix of possible remedies or defenses. Gradually, the litigation process will help to separate fact from fiction regarding hydraulic fracturing. ${ }^{58}$

The other category of torts will involve basic negligence claims against a service provider. ${ }^{59}$ Although the operator hiring the service provider will typically have a contractual relationship, non-contracting parties impacted by negligent hydraulic fracturing services will have to rely upon tort law for a remedy ${ }^{60}$ Hydraulic fracturing services should not present anything unique in this part of the tort arena. Anything that can be done right can be done wrong. The major issues, as in any tort of this type, are proving the contractor's negligence and damages resulting from the negligence.

\section{THE CONTRACT DIMENSION OF HYDRAULIC FRACTURING}

The availability of hydraulic fracturing has proven to be a game-changer in a number of reservoirs. ${ }^{61}$ As noted by the Oklahoma Supreme Court in a 1965 case, the lessee's obligation to further develop leased lands ${ }^{62}$ was directly impacted by "the advent of sandfracing." "63 The court relied upon the

58. Because the ability to use hydraulic fracturing will ultimately determine whether huge new areas are subjected to intense oil and gas development, killing hydraulic fracturing becomes a means for killing development. Because oil and gas are major sources of carbon dioxide, those who believe climate change is anthropogenic, and avoidable, will view it as a moral imperative to prevent any expansion of oil and gas development. As a moral imperative, no tactic is too extreme, particularly when the alternative is touted as destruction of the earth.

59. See generally Geo Viking, Inc. v. Tex-Lee Operating Co., No. D-1678, 1992 WL 80263 (Tex. Apr. 22, 1992), withdrawn, 839 S.W.2d 797 (Tex. 1992) (suit to recover damages under the Texas Deceptive Trade Practices Act for an improperly performed hydraulic fracturing job on an oil well).

60. One potentially unique issue is the measure of damages. The focus in the Geo Viking case was whether damages for an improper frac job should include the value of drainage from an adjacent tract that would have been facilitated by a proper frac job. Geo Viking, Inc., 1992 WL 80263, at*1 (trial court refused to give limiting instruction).

61. Recall the 1953 testimonial by oilman Ben Gralapp and the 1965 report by geologist William S. Lytle. See supra notes 6-11 and accompanying text. In a 1959 proceeding the court's finding of facts included the following: "But for the process of hydraulic fracturing which was invented about 1949 and first used in Pennsylvania in 1954, no gas in productive or commercial quantities would have been discovered in or produced from Warrant 2001 or Huston Township." New York State Natural Gas Corp. v. Swan-Finch Gas Dev. Corp., 173 F. Supp. 184, 198 (W.D. Pa. 1959) (finding of fact 947 ).

62. The leased lands were "held by production," or "HBP," through production from wells completed in the formation which the plaintiffs complained should have been more fully developed by drilling additional wells at undrilled locations on the lease.

63. Crocker v. Humble Oil \& Ref. Co., 419 P.2d 265, 271 (Okla. 1965) (lessee observing that "no reasonable or prudent operator would drill additional wells on the lease until after the advent of 
acceptance of sandfracing in the existing reservoir as a sort of two-edged sword to evaluate the lessors' development claims: the lessee's failure to develop prior to the use of sandfracing in the field was excusable; ${ }^{64}$ the lessee's failure to develop once sandfracing became a proven technique, was not excusable. ${ }^{65}$

Once hydraulic fracturing is proven to promote profitable development of a reservoir, it can impact the oil and gas lessee in at least three ways: first, as an efficient, cost-effective technique to increase production from existing wells; second, as a justification for developing new portions of known reservoirs; and third, as a justification for offsetting wells that have been fractured on adjacent lands to prevent uncompensated drainage.

To determine whether action must be taken to employ hydraulic fracturing techniques, courts will be guided by what a prudent operator would do under the circumstances. The circumstances will include the degree to which the technique has been proven in the reservoir at issue as well as the costs and potential risks and rewards. The best way to evaluate the lessee's conduct, applying a truly objective standard, is to inquire: what would the lessee do if it only owned one lease-the lease at issue. It does not matter how many leases the developer may have, or where they are located, so long as the analysis seeks to determine what a prudent operator would do if they owned but one lease.

\section{CONCLUSIONS}

As with any industrial process beneficial to society, the common law of hydraulic fracturing will evolve to accommodate the activity while policing its attendant risks. Although the general direction of the common law to date

sandfracing.").

64. The Oklahoma Supreme Court affirmed the following trial court finding:

The court finds that the drilling of another well on said NW 1/4 NE 1/4 NW 1/4 of Section 16 would not have been a prudent or paying operation until after the discovery and availability of hydraulic-fracturing process, but that after such time the drilling of such well would probably be a profitable and paying proposition.

Id. at 271 (trial court's finding); Id. at 273 (Supreme Court affirming trial court's finding).

65. The court in Crocker relied upon the following evidence to find that the lessee failed to prudently develop a portion of the leased land:

The defendant admits the use and value of sandfracing. During the years 1957-1961 the defendant sandfraced 100 wells. The defendant cannot offer any reasonable excuse in its failure to utilize the sandfracing process for further development of the cancelled portion of the lease. Id. at 274. 
has taken a detour provided by the rule of capture, ${ }^{66}$ facts surrounding the reservoir community where the activity takes place should dictate the law's ultimate path. To properly account for the existence of a reservoir community where hydraulic fracturing takes place, courts must accurately define the extraterritorial rights of owners within the reservoir. Only by recognizing the collective rights of the community can the rights and obligations of individual community members be fully defined. This process will provide the guidance necessary to accurately respond to issues such as whether a fissure that crosses surface boundary lines into a community member's space is an affront to the reservoir community or welcomed prudent development.

Once hydraulic fracturing is proven to enhance production from a particular reservoir, lessors of lands within the reservoir, as a matter of private contract, will demand that their lessees diligently pursue the technique. As with any industrial process, things will go wrong. For those situations, the common law will respond to provide a remedy against negligent and willful conduct. Because hydraulic fracturing is now perceived as impacting a new array of private and public interests, the common law will have to evolve to account for legislative initiatives that appear inevitable at this time.

66. See supra notes $46-47$ and accompanying text. The rule of capture has provided many significant detours in the law governing oil and gas; enough to warrant a separate book on the subject. See generally Terence Daintith, Finders Keepers? How the Law of Capture Shaped the World Oil INDUSTRY (2010). 